\title{
Pre-emptive Breeding Against Karnal Bunt Infection in Common Wheat: Combining Genomic and Agronomic Information to Identify Suitable Parents
}

\begin{abstract}
Livinus Emebiri,2*, Shane Hildebrand ${ }^{1}$, Mui-Keng Tan ${ }^{3}$, Philomin Juliana ${ }^{4}$, Pawan K. Singh ${ }^{4 *}$, Guillermo Fuentes-Davila ${ }^{5}$ and Ravi P. Singh ${ }^{4}$

${ }^{1}$ NSW Department of Primary Industries, Wagga Wagga Agricultural Institute, Wagga Wagga, NSW, Australia, ${ }^{2}$ Graham Centre for Agricultural Innovation (NSW Department of Primary Industries and Charles Sturt University), Wagga Wagga, NSW, Australia, ${ }^{3}$ NSW Department of Primary Industries, Menangle, NSW, Australia, ${ }^{4}$ International Maize and Wheat Improvement Center, Mexico City, Mexico, ${ }^{5}$ Instituto Nacional de Investigaciones Forestales, Agricolas y Pecuarias, Cd. Obregón, Mexico
\end{abstract}

OPEN ACCESS

Edited by:

Valerio Hoyos-Villegas, McGill University, Canada

Reviewed by:

Devanna B N

National Rice Research Institute (ICAR), India

Yong Suk Chung, Jeju National University, South Korea

*Correspondence: Pawan K. Singh

Pk.Singh@cgiar.org Livinus Emebiri livinus.emebiri@dpi.nsw.gov.au

Specialty section: This article was submitted to Plant Breeding,

a section of the journal Frontiers in Plant Science

Received: 04 March 2021 Accepted: 18 May 2021 Published: 29 July 2021

Citation:

Emebiri L, Hildebrand S, Tan M-K, Juliana P, Singh PK, Fuentes-Davila G and Singh RP (2021) Pre-emptive

Breeding Against Karnal Bunt Infection in Common Wheat: Combining Genomic and Agronomic Information to Identify Suitable Parents. Front. Plant Sci. 12:675859. doi: 10.3389/fpls.2021.675859
Wheat (Triticum aestivum L.) is the most widely grown cereal crop in the world and is staple food to half the world's population. The current world population is expected to reach 9.8 billion people by 2050, but food production is not expected to keep pace with demand in developing countries. Significant opportunities exist for traditional grain exporters to produce and export greater amounts of wheat to fill the gap. Karnal bunt, however, is a major threat, due to its use as a non-tariff trade barrier by several wheat-importing countries. The cultivation of resistant varieties remains the most costeffective approach to manage the disease, but in countries that are free of the disease, genetic improvement is difficult due to quarantine restrictions. Here we report a study on pre-emptive breeding designed to identify linked molecular markers, evaluate the prospects of genomic selection as a tool, and prioritise wheat genotypes suitable for use as parents. In a genome-wide association (GWAS) study, we identified six DArTsea markers significantly linked to Karnal bunt resistance, which explained between 7.6 and $29.5 \%$ of the observed phenotypic variation. The accuracy of genomic prediction was estimated to vary between 0.53 and 0.56 , depending on whether it is based solely on the identified Quantitative trait loci (QTL) markers or the use of genome-wide markers. As genotypes used as parents would be required to possess good yield and phenology, further research was conducted to assess the agronomic value of Karnal bunt resistant germplasm from the International Maize and Wheat Improvement Center (CIMMYT). We identified an ideal genotype, ZVS13_385, which possessed similar agronomic attributes to the highly successful Australian wheat variety, Mace. It is phenotypically resistant to Karnal bunt infection ( $<1 \%$ infection) and carried all the favourable alleles detected for resistance in this study. The identification of a genotype combining Karnal bunt resistance with adaptive agronomic traits overcomes the concerns of breeders regarding yield penalty in the absence of the disease.

Keywords: Karnal bunt resistance, Tilletia indica, wheat, Triticum aestivum, genome-wide association study, GWAS, genomic prediction, grain yield 


\section{INTRODUCTION}

Wheat (Triticum aestivum L.) is the most widely grown cereal crop on the planet, a staple of the world economy, supplying one fifth of calories consumed by people each day (Anonymous, 2020). The current world population of about 7.7 billion is expected to increase and reach 9.8 billion people by 2050 . To accommodate the increased demand for food, annual cereal production will need to rise by about $60-70 \%$ from the current level of 2.8 billion tonnes. For various reasons, however, production is not expected to keep pace with demand in developing countries, and their net imports of cereals are projected to more than double from 135 million metric tonnes in 2008/2009 to 300 million metric tonnes in 2050 (Food Agriculture Organization 2009). This gap can be bridged by increased imports, and significant opportunities exist for traditional grain exporters, including Australia, to produce and export greater amounts of wheat over the next few decades (Linehan et al., 2012). Karnal bunt, a disease caused by the fungus Tilletia indica Mitra [syn. Neovossia indica (Mitra) Mundkur], is a threat to grain export (Joshi et al., 1983), due to its use as a non-tariff trade barrier by several wheat-importing countries (Beattie and Biggerstaff, 1999). The disease has minimal impact on wheat grain yield (Warham, 1986; Murray and Brennan, 1998) but the infected grains exude an unpleasant, rotten fish odour due to a chemical (trimethylamine) produced by the fungal spores (Mitra, 1935). Trimethylamine is associated with multiple diseases in humans, including renal disorders, cancer, obesity, and cardiovascular diseases (Chhibber-Goel et al., 2016).

Control of this disease is difficult because teliospores of the fungus are resistant to physical and chemical factors (FuentesDávila et al., 2018), the fungus causes local infections (FuentesDavila, 1996), and teliospores may remain dormant for more than 32 months (Babadoost et al., 2004). The cultivation of resistant varieties remains the most cost-effective approach to manage the threat of incursions into countries free of the disease (Singh et al., 2007; Emebiri et al., 2019a). Sources of resistance have been identified in the wild relative of wheat, Aegilops tauschii (Chhuneja et al., 2008), and in synthetic hexaploid wheat (Mujeeb-Kazi et al., 2006), but resistance in common wheat is limited (Fuentes-Dávila and Rajaram, 1994), and as such, progress in breeding resistant varieties has remained modest. In most wheat-exporting countries that are free of the disease, there are no breeding efforts due to cost burdens and the low return on investments, which in the absence of an incursion, is zero (White et al., 2016). Availability of molecular markers closely linked to resistance genes could be incentivising, as it has the potential to improve selection (Singh et al., 2012; Emebiri et al., 2019b), but efforts in the past have also been modest. Quantitative trait loci (QTL) associated with Karnal bunt resistance in common wheat have been identified in the past (Nelson et al., 1998; Singh et al., 2003; Singh et al., 2007, 2012; Kumar et al., 2007, 2015; Kaur et al., 2016), but these studies were based on a small number of restriction fragment length polymorphisms (RFLP) and PCR-based simple sequence repeats (SSRs). Recently, the use of high-density single nucleotide polymorphism (SNP) arrays in genome-wide association studies (GWAS) have been reported
(Brar et al., 2018; Emebiri et al., 2019b; Gupta et al., 2019; Singh et al., 2020), which offers new opportunities for markerassisted selection (MAS). However, the focus of many plant breeders has now shifted from the use of MAS to the application of genomic selection.

Genomic selection, first introduced by Meuwissen et al. (2001), would be an attractive tool for pre-emptive breeding against exotic pathogens, as it would reduce the challenges of phenotyping (Poland and Rutkoski, 2016). Genomic selection is a two-stage process in which whole-genome markers are used to predict genomic estimated breeding value (GEBV) of individuals in a population, and then selection decisions are made on the basis of these GEBVs (Meuwissen et al., 2001). In the bestcase scenario, breeders can select the best performing genotypes from the population for use in their crossing block, without the need to phenotype the plants themselves. The potential for genomic selection has yet to be evaluated for Karnal bunt resistance in common wheat. The prediction accuracy depends on the trait's heritability, and for Karnal bunt resistance, the estimates are quite high (ranging from 0.75 to 0.91) (Brar et al., 2018; Emebiri et al., 2019a; Gupta et al., 2019; Singh et al., 2020) due to the well-established protocol for disease screening (Fuentes-Dávila et al., 1995).

The International Maize and Wheat Improvement Center (CIMMYT), Mexico, develops novel common wheat germplasm carrying Karnal bunt resistance genes (Singh et al., 2016). Some of the lines were derived from crosses that include Munal\#1 (now released as Super 172) and synthetic hexaploids (MujeebKazi et al., 2006) as parents, and some were developed from backcrosses to commercial varieties, such as Batavia, and Pastor. The lines are important pre-emptive breeding tools to prevent the spread of this quarantined disease into countries that are currently disease-free. However, many other variables are involved in grower uptake of new varieties, with grain yield as the ultimate determinant of which variety the farmer will grow in any given season. In the absence of a disease pressure, genetic resistance may in fact become a liability (yield penalty), as demonstrated in numerous studies (Brown, 2002; Ning et al., 2017). Sharp et al. (2002), for instance, observed that while the Wsm 1 gene in wheat provided the most effective resistance to wheat streak mosaic virus, a mean yield reduction of $21 \%$ occurred in the absence of the virus. The wheat stem rust resistance gene, Sr26, has a $9 \%$ yield penalty (Brown, 2002), and the barley (Hordeum vulgare) mlo resistance gene has a $4.2 \%$ yield penalty (Jorgensen, 1992). This is because genetic resistance is an on-going process, and plants expend metabolic energy that might otherwise be converted to yield. In the absence of the pathogen, existence of a yield penalty for Karnal bunt resistance will outweight the value of the resistance gene (Oliver et al., 2014; Ning et al., 2017), and breeders will be further discouraged from adopting and using improved germplasm in their programmes for fear of upsetting the established phenology and yield profiles.

The key to pre-emptive breeding would be to provide breeders with a package of molecular markers and resistance genes in genetic backgrounds that will not upset established yield and phenology profiles, as there is no point selecting less susceptible varieties if there is an opportunity cost of lower yield without 
disease. In this paper, we report a research on pre-emptive breeding for Karnal bunt resistance designed to identify linked molecular markers, assess prospects of genomic selection as a tool, and prioritise wheat genotypes suitable for use as parents. To identify such genotypes, we performed field experiments over two years to compare their agronomic values with those of reference, commercial varieties.

\section{MATERIALS AND METHODS}

\section{Plant Materials}

The germplasm materials consisted of 242 genotypes, made up of 177 bread wheat varieties, 8 durum wheat, 11 triticale, and 46 Karnal bunt-resistant germplasm lines (KBRL). The KBRL were developed at the CIMMYT, and imported into Australia through the CIMMYT-Australia-ICARDA Germplasm Evaluation (CAIGE) suite of projects. ${ }^{1}$ The wheat varieties represent parents used in breeding programmes, historical varieties, and current commercial varieties that are still being cultivated. These were mainly bred in Australia, but some originated from the United States, Brazil, Canada, China, Mexico, New Zealand, and India, providing a global resource for genetic analysis. The bread wheat lines include Super172 (synonym Munal-\#1), used as the resistant check, and the highly susceptible Indian wheat variety WL-711 (synonym WL-711-0IND) used as a susceptible check. The names of the varieties, year of release and pedigrees are listed in Supplememntary Table 1.

\section{Disease Phenotyping}

Phenotypic data on Karnal bunt resistance collected from Australian wheat varieties and CIMMYT advanced breeding lines were used. The data for the Australian varieties were derived from field experiments (Emebiri et al., 2019a) conducted during three consecutive cropping seasons (2014-2015, 2015-2016, and 2016-2017), at the Norman E. Borlaug Experimental Station, the CIMMYT, Obregon. The data on CIMMYT breeding lines, collected over three planting dates, were kindly provided by Dr. Ravi P. Singh as part of the materials delivered through CAIGE project. In these data, Karnal bunt resistance was calculated as the percentage of infected grains in each ear (Fuentes-Dávila and Rajaram, 1994), but to rate the genotypes consistently across data sets, those with infection levels of $0-2.5 \%$ were rated as resistant, $2.6-5 \%$ as moderately resistant, $5.1-10 \%$ as moderately susceptible and greater than $10 \%$ as susceptible (Gaudet et al., 2001).

\section{Genotyping}

Genomic DNA was isolated from the leaves of individual lines as described in Tan et al. (2015) and genotyped using DArTSeq technology (Diversity Arrays Technology Pty Ltd., Australia). The polymorphisms were scored as binary data $(0 / 1)$, indicating the presence/absence of SNP in the genome of each sample. The DArTseq data were filtered for quality, first by removing duplicates and monomorphic markers; then by retaining markers

\footnotetext{
${ }^{1}$ http://caigeproject.org.au/
}

on the basis of CallRate $(\geq 0.95)$, reproducibility $(\geq 0.95)$, minor allele frequency $(\geq 0.05)$, and percent missing data $(\leq 15 \%)$. The final molecular marker data set comprised of 8,012 loci scored on 177 hexaploid genotypes. All heterozygotes were treated as missing data, and the corresponding values were imputed using the Random Forest regression method in $\mathrm{R}$ package (Stekhoven and Bühlmann, 2012).

\section{Genetic Structure and Linkage Disequlibrium}

Genetic structure was analysed using algorithms implemented in the adegenet package (Jombart, 2008). First, we ran the snapclust function to select the optimal number of genetic groups, based on a statistical measure of goodness of fit, the Bayesian Information Criterion (BIC). Then, a discriminant analysis of principal components (DAPC) was applied, which combined PCA with discriminant analysis to maximise betweengroup differences while minimising the within-group variation (Jombart et al., 2010).

Linkage disequilibrium (LD) (statistical association between allelic variants) was calculated in plink v1.9 (Purcell et al., 2007) as the squared correlation coefficient $\left(r^{2}\right)$ between alleles at pairs of loci within each chromosome. The analyses were carried out with a molecular data set that was thinned down evenly across the genome to a window size of $8 \mathrm{~kb}$. The decay of LD over genetic distance was examined by plotting the pair-wise LD against distance, and fitting a decay curve, established by square root transformation of the predicted LD values calculated according to Andreescu et al. (2007). The background $r^{2}$ value was calculated as the $95^{\text {th }}$ percentile of all LD values between markers located on different chromosomes, assumed to unlinked (Breseghello and Sorrells, 2006).

\section{Genome-Wide Association Analysis}

Genome-wide analyses were performed with the $\mathrm{R}$ package, lmem.gwaser (Gutierrez et al., 2016), according to the Kinship model, which had a lambda value of 1.03 . It can be described as follow:

$$
y=x \beta+z u+\varepsilon
$$

where $y$ is the observed phenotype, $x$ is the molecular marker score matrix, $\beta$ is the vector of marker allelic effects, $z$ is an incidence matrix, $u$ is a vector of random polygene background effects with $\operatorname{Var}(\mathrm{u})$ being $2 \mathrm{KV}_{G}(\mathrm{~K}=$ Kinship coefficients and $\mathrm{V}_{G}=$ genetic variance), and $\varepsilon$ is a vector of random experimental error.

We adjusted observed $P$-value for multiple testing using two methods: the method of Li and Ji (2005), which is based on the effective number of independent tests (alpha level of 0.05 ) and the false discovery rate (FDR) method of Benjamini and Hochberg (1995). The method of Li and Ji (2005) was implemented in the lmem.gwaser package but FDR was calculated in the $\mathrm{R}$ function, p.adjust(). Allelic effects and proportion of phenotypic variance ( $R^{2}$-values) explained by significant markers were derived from simple linear regression analyses, with $R^{2}=\mathrm{SS}_{r e g} / \mathrm{SS}_{t o t}$, where $\mathrm{SS}_{r e g}$ is the regression sum of squares and $\mathrm{SS}_{\text {tot }}$ is the total sum of squares. 


\section{Physical Mapping}

Significant markers were assigned to physical positions in megabase pairs (Mbp) by nucleotide BLAST (BLASTN) search (E-value threshold $=1 \mathrm{E}-5)$ against the IWGSC RefSeq v1.0 Chinese Spring assembly, ${ }^{2}$ using the marker sequence for query. High-confidence candidate genes closely matching the marker sequence were obtained in a window size of estimated LD each side of the marker. The results were further refined with the JBrowse tool (Buels et al., 2016) to identify nearby wheat expressed sequence tags ( $\mathrm{wEST}$ ), and this allowed assigning the markers to physical bin positions on the deletion maps of the Chinese Spring cultivar.

\section{Prediction of Karnal Bunt Resistance}

Two scenarios were considered for genomic prediction: (1) the use of only the markers identified in GWAS analysis (QGBLUP), analogous to marker-assisted selection strategy and (2) the use of genome-wide markers to predict the performance of individuals for which genotypic data is available, but not the phenotypes. The analysis was carried out using the genomic best linear unbiased prediction (GBLUP) model (Meuwissen et al., 2001), in which the G-matrix was calculated using either the six significant markers identified in GWAS, or the genome-wide markers, depending on the approach. In both cases, accuracies were determined from a fivefold cross-validation scheme, in which $80 \%$ of the genotypes were randomly assigned to a training set (TRN) and the remaining $20 \%$ to a testing set (TSN). This was repeated 100 times, and for each repeat, the individuals in the TRN and TSN set were randomly re-sampled, the phenotypes of individuals in the TST set were masked, and then predicted based on the TRN set. Genomic prediction accuracy was calculated as the Pearson's correlation between the actual and the predicted phenotypes of the lines in the TSN set.

\section{Agronomic Assessment}

Field experiments were carried out in 2015 and 2016 cropping seasons to assess the agronomic value of Karnal bunt-resistant lines. For this study, 37 of the Karnal bunt resistant lines from CIMMYT were used. Seven commercial wheat varieties were included as reference genotypes. These included Super172 (syn. Munal\#1), Axe, Mace, Rosella, Scout, Suntop, and Waagan. Axe was released in 2007 and is a very early maturing wheat that is suited for short growing seasons, while Mace, released in 2008, has broad adaptation, with consistently high yield under a wide range of conditions. Rosella is a widely adapted winter wheat used for dual-purpose grazing, while Suntop was released in 2011 as a main season line, with high and stable yields from low to high yield potential areas. Both Scout and Waagan were released in 2009. Scout is a mid-season maturity variety with low screenings and high test weight, and Waagan is a very early maturing spring wheat, with high yield potential in medium/low rainfall environments.

The experiments were conducted at the Wagga Wagga Agricultural Institute, Wagga Wagga NSW, Australia (latitude $35.05^{\circ} \mathrm{S}$, longitude $147.35^{\circ} \mathrm{E}$ ), on a site with well-drained, sandy

${ }^{2}$ https://urgi.versailles.inra.fr/blast/ clay loam soil with a greyish brown colour. The experiments were arrayed in a row-column, $p$-rep design (Cullis Brian et al., 2006), with experimental units (plots) measuring $7.5 \mathrm{~m}^{2}$ in area (six rows with $30 \mathrm{~cm}$ spacing, $6 \mathrm{~m}$ long, trimmed to $5 \mathrm{~m}$ prior to harvest). Plots were sown with a tractor-mounted Seeder, at a rate of 60 -g seeds per plot. All experiments were fertilised at the time of sowing with monoammonium phosphate at the rate of $100 \mathrm{~kg} / \mathrm{ha}$, and standard operational procedures (irrigation, weed, pest/disease control) were applied.

\section{Statistical Analysis of Agronomic Data}

Data on the following agronomic traits were collected: emergence counts (number of plants per plot), flowering date (50\% awn emergence), plant height (height from soil to tip of the awns), NDVI (at anthesis using the GreenSeeker) and grain yield (weight of the uncleaned seed weight from machine harvests per plot). At harvest, the uncleaned grains $(300 \mathrm{~g})$ were subsampled and used to collect data on grain size (1,000 grain weight) and grain plumpness (grains retained over a $2.5 \mathrm{~mm}$ sieve).

A two stage approach was used for data analysis. In the first stage, each trait within an experiment/year was analysed separately to account for design factors and spatial field variation. This was performed using a mixed linear model framework with spatial corrections for field heterogeneity as implemented in the R package, SpATS (Rodríguez-Álvarez et al., 2018). The analytical model included data on seedling emergence (count) per plot as a fixed component to adjust for differences in plant density. SpATS uses two-dimensional smoothing surfaces with penalised splines to model the spatial trends within the field and obtain estimates of predicted means. In the second stage, adjusted means for the 2 years were jointly modelled to generate variance components, and a genotype $\times$ trait matrix, which was analysed according to the genotype plus genotype-byenvironment method, as implemented in GGEBiplotGUI (Frutos et al., 2014). Graphical displays of the output were aided by the $\mathrm{R}$ package, ggplot2 (Ginestet, 2011).

\section{RESULTS}

\section{Phenotypic Variation}

Broad-sense heritability of Karnal bunt resistance, calculated as the ratio of genotypic to phenotypic variance components, was $0.83 \pm 0.02$, and for narrow-sense heritability, calculated using a marker-based approach (Covarrubias-Pazaran, 2016), the estimate was relatively high at $0.61 \pm 0.14$. These estimates indicated a large contribution of genetic factors to Karnal bunt resistance in the wheat accessions. The average percentage infection in the wheat accessions was $17.5 \%$, with a range of $0.4-51.8 \%$. There were 10 resistant lines, that is, genotypes with seed infection levels of $0-2.5 \%$. These included seven KBRL and three cultivated varieties. Sixteen of the accessions were moderately resistant (\% KB infection $>2.5-5 \%$ ), 46 were moderately susceptible $(>5-10 \%)$ and 105 were susceptible $(\% \mathrm{~KB}$ infection $>10 \%$ ). 
A

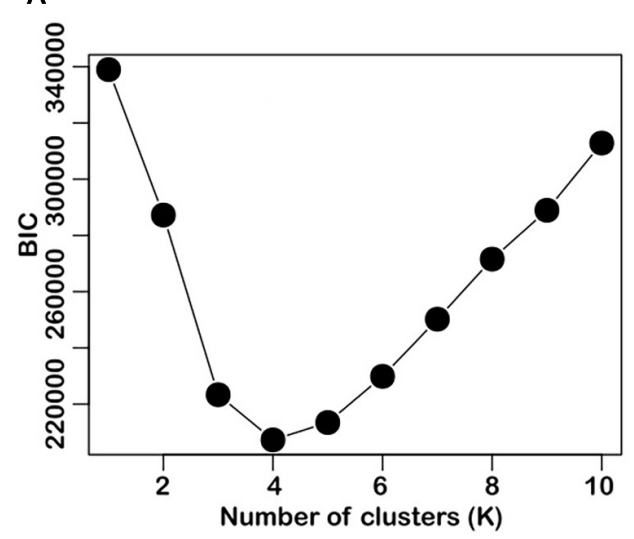

B

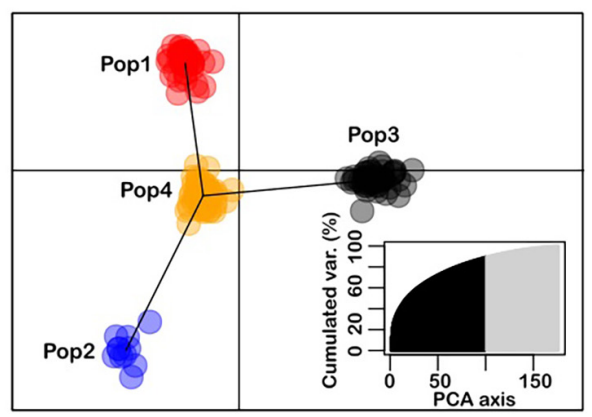

FIGURE 1 | Population structure in the panel of 177 wheat accessions used for the study. Panel (A) is the optimal number of clusters identified with the find.cluster function in adegenet (Jombart, 2008). Panel (B) is the DAPC results, showing relative positions of individuals and genetic clusters in the discriminant space (inset is the PCA eigenvalues).

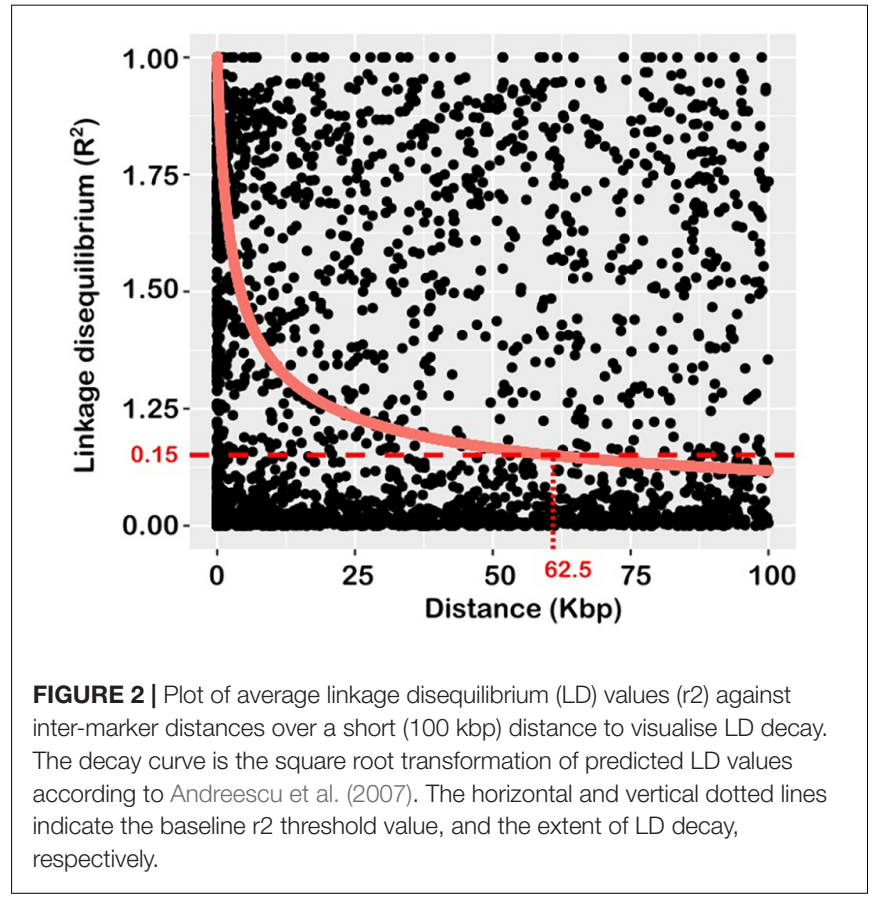

\section{Genetic Structure}

Genetic structure analysis was performed to determine whether the composition of wheat accessions was structured, that is, differentiated into clusters of closely related individuals, and which individuals belong to which clusters. Graph of BIC values showed a minimum value at $\mathrm{K}=4$, and this was determined to be the optimal number of genetic clusters in the wheat accessions (Figure 1A). The DAPC analysis showed clear separation of the accessions into four genetic clusters (Figure 1B), with sample sizes ranging from 11 to 79. It was noteworthy that the CIMMYTderived Karnal bunt resistant lines cluster together in Pop3 $(\mathrm{n}=46)$, and along with varieties such as Seri-M82, Pastor,
TABLE 1 | Summary of significant markers detected in association mapping of Karnal bunt resistance in common wheat.

\begin{tabular}{|c|c|c|c|c|c|c|c|}
\hline $\begin{array}{l}\text { Peak } \\
\text { marker }\end{array}$ & Chr. & $\begin{array}{l}\text { Physical } \\
\text { position } \\
\text { (Mb) }\end{array}$ & $\begin{array}{l}\text { Deletion } \\
\text { bin }\end{array}$ & $P$-value & $\begin{array}{l}\text { FDR- } \\
\text { value }\end{array}$ & $\begin{array}{l}\text { Allelic } \\
\text { effect }\end{array}$ & $\begin{array}{c}\text { R-squared } \\
(\%)\end{array}$ \\
\hline 2282741 & $1 \mathrm{~A}$ & 481.52 & $\begin{array}{c}\text { 1AL1-0.17- } \\
0.61\end{array}$ & 2.08E-05 & $\begin{array}{c}\text { 3.33E- } \\
02\end{array}$ & 1.10 & 26.91 \\
\hline 1249729 & $2 \mathrm{~A}$ & 723.62 & $\begin{array}{c}\text { C-2AL1- } \\
0.85\end{array}$ & $1.45 \mathrm{E}-04$ & $\begin{array}{c}1.16 \mathrm{E}- \\
01\end{array}$ & 0.92 & 7.58 \\
\hline 1037716 & $3 B$ & 618.02 & $\begin{array}{c}\text { 3BL10- } \\
0.50-0.63\end{array}$ & 7.64E-07 & $\begin{array}{c}6.12 \mathrm{E}- \\
03\end{array}$ & -1.04 & 29.47 \\
\hline 993727 & $4 \mathrm{~A}$ & 719.43 & $\begin{array}{c}\text { 4AL4-0.80- } \\
1.00\end{array}$ & 4.44E-05 & $\begin{array}{c}5.08 \mathrm{E}- \\
02\end{array}$ & -1.03 & 26.31 \\
\hline 1128414 & $5 A$ & 618.27 & $\begin{array}{c}\text { 5AL17- } \\
0.78-0.87\end{array}$ & 6.07E-06 & $\begin{array}{c}2.43 \mathrm{E}- \\
02\end{array}$ & -1.06 & 27.87 \\
\hline 989877 & $6 B$ & 683.23 & $\begin{array}{c}\text { 6BL5-0.40- } \\
1.00\end{array}$ & 3.06E-04 & $\begin{array}{c}1.88 \mathrm{E}- \\
01\end{array}$ & 0.26 & 8.09 \\
\hline
\end{tabular}

Nominal P-values were adjusted using the false discovery rate (FDR) method of Benjamini and Hochberg (1995); the explained variation (R-squared) and allelic effects attributable to each marker were derived from simple linear regression analyses.

Genaro-F81, and Veery5, they were separate from the other wheat genotypes. Seri-M82 and Genaro-F81 are semi-dwarf, historical wheat varieties from CIMMYT, and Pastor is derived from a cross involving Ser-M82 as a parent. The genotypes in Pop1 $(n=41)$ and Pop2 $(n=11)$ were Australian-bred wheat varieties, and those in Pop4 $(N=79)$ were a mixture of global wheat genotypes. They include Australian varieties such as Axe, Drysdale and EGA-Burke, the Indian variety WL-711, Canadian varieties such as $\mathrm{AC}$-Domain and its progeny, $\mathrm{AC}$-Snowbird, the Chinese variety, Chuan-Mai-18, the Brazilian variety, Carazinho and the USA variety, Angus.

Linkage disequilibrium (statistical association between allelic variants) and its decay rate were examined using pair-wise combinations of markers genotyped across the 21 wheat chromosomes. The estimate of background LD, calculated from 
A

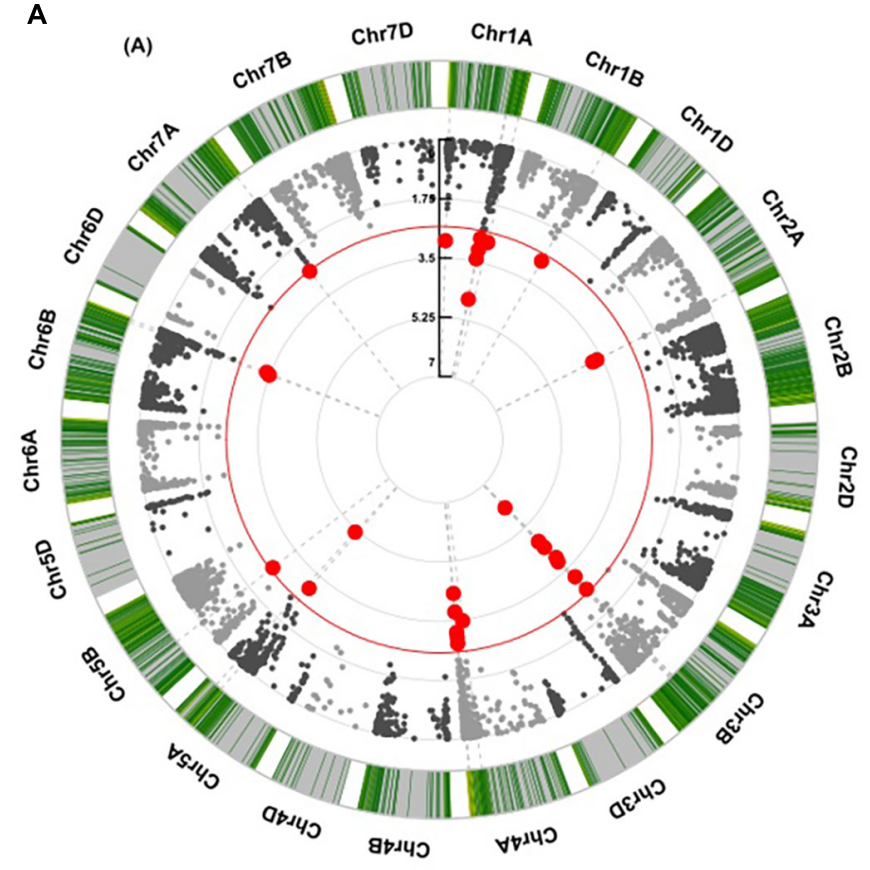

B
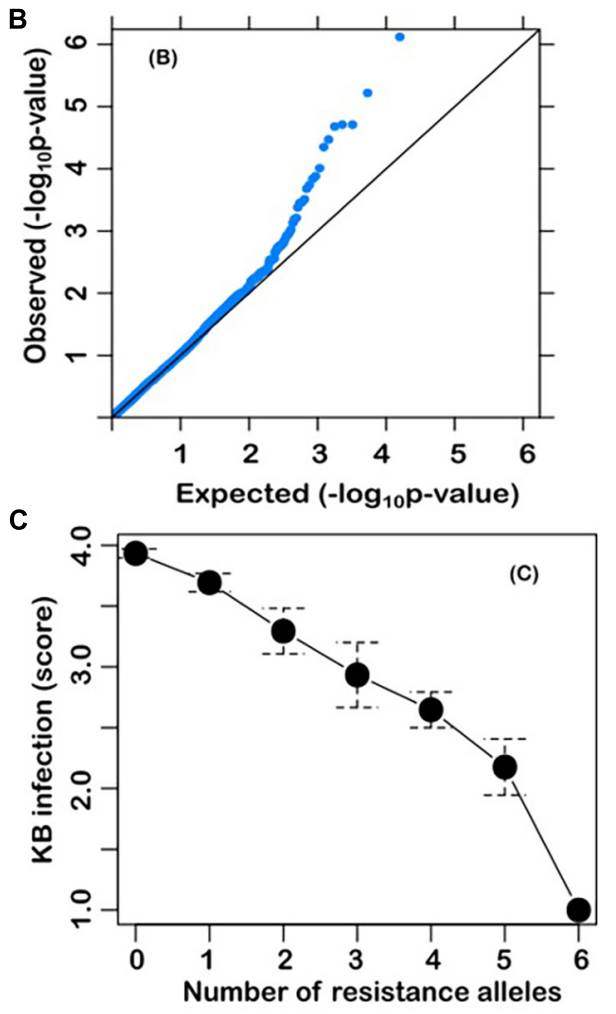

FIGURE 3 | (A) Circular Manhattan plot from genome-wide scan with a mixed linear model. The red line is the significance threshold; (B) QQ plots from genome-wide scan. The late separation between observed and expected P-values in the upper left section represents the significant associations; and (C) Relationship between number of favourable alleles and Karnal bunt resistance in the wheat accessions.

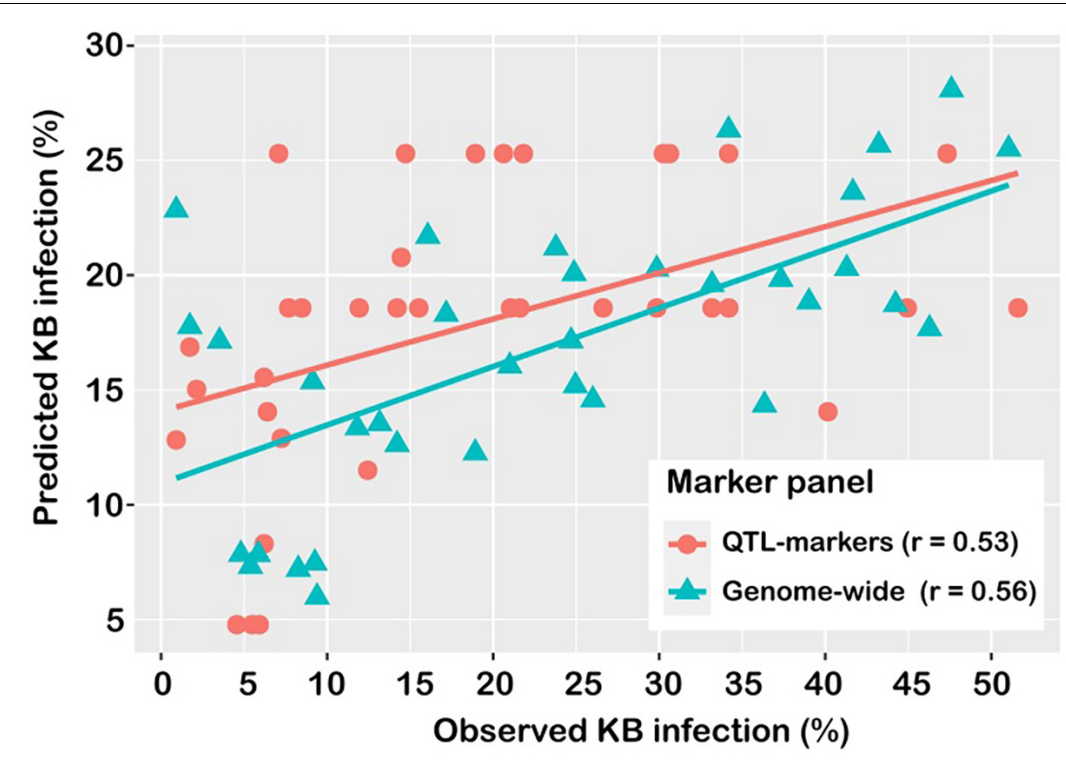

FIGURE 4 | Prediction accuracy of models for Karnal bunt resistance, using markers detected in GWAS analysis (QTL), and genome-wide markers (WG).

$r^{2}$ values of unlinked markers was 0.15 , which agrees with the value commonly reported for wheat (Joukhadar et al., 2020). This value intersected the LD decay line at $62.5 \mathrm{Kbp}$ (Figure 2), and this represents the extent of LD in the population used for this study. It represents the mapping resolution of any QTL detected and was used as the confidence interval. 
TABLE 2 | Spatially adjusted means of check varieties and CIMMYT-derived, Karnal bunt resistant germplasm.

\begin{tabular}{|c|c|c|c|c|c|c|c|}
\hline Source & $\begin{array}{l}\text { Disease } \\
\text { rating }\end{array}$ & $\begin{array}{c}\text { Grain } \\
\text { yield } \\
\left(\mathrm{t} \mathrm{ha}^{-1}\right)\end{array}$ & $\begin{array}{l}\text { Flowering } \\
\text { date } \\
\text { (days) }\end{array}$ & $\begin{array}{c}\text { Plant } \\
\text { height } \\
\text { (cm) }\end{array}$ & $\begin{array}{c}1,000 \\
\text { Kernel } \\
\text { weight } \\
\text { (g) }\end{array}$ & NDVI & $\begin{array}{c}\text { Plump } \\
\text { grains } \\
(\%)\end{array}$ \\
\hline$\sigma^{2}$ genetic & & 1.14 & 22.51 & 68.44 & 42.47 & 0.00 & 17.96 \\
\hline$\sigma^{2}$ residual & & 0.14 & 4.18 & 12.56 & 2.84 & 0.00 & 5.343 \\
\hline Heritability & & 0.94 & 0.92 & 0.92 & 0.97 & 0.87 & 0.87 \\
\hline SE heritability & & 0.08 & 0.11 & 0.11 & 0.04 & 0.16 & 0.16 \\
\hline \multicolumn{8}{|c|}{ Adjusted genotype means } \\
\hline Axe & S & 4.75 & 128.64 & 85.72 & 43.90 & 0.57 & 91.83 \\
\hline Mace & S & 5.11 & 128.75 & 91.28 & 41.90 & 0.57 & 89.83 \\
\hline Rosella & S & 5.04 & 135.14 & 97.26 & 38.02 & 0.51 & 85.17 \\
\hline Scout & S & 5.56 & 129.55 & 92.28 & 44.76 & 0.58 & 91.72 \\
\hline Suntop & S & 5.26 & 130.28 & 94.08 & 41.78 & 0.60 & 84.34 \\
\hline Super172 & $\mathrm{R}$ & 4.92 & 130.34 & 94.66 & 45.11 & 0.59 & 89.02 \\
\hline Waagan & S & 5.45 & 128.54 & 86.36 & 41.06 & 0.57 & 90.39 \\
\hline ZVS13_312 & MR & 5.35 & 130.31 & 93.75 & 47.87 & 0.59 & 91.02 \\
\hline ZVS13_316 & MS & 4.84 & 129.95 & 91.07 & 47.44 & 0.61 & 91.68 \\
\hline ZVS13_385 & $\mathrm{R}$ & 4.69 & 128.34 & 89.51 & 43.93 & 0.57 & 89.94 \\
\hline ZVS13_404 & MS & 5.15 & 129.13 & 97.73 & 44.57 & 0.60 & 90.96 \\
\hline ZVS13_406 & $\mathrm{MR}$ & 4.46 & 128.54 & 89.66 & 49.69 & 0.59 & 88.86 \\
\hline ZVS13_441 & MS & 4.79 & 129.29 & 99.56 & 44.67 & 0.61 & 92.24 \\
\hline ZWB10_44 & $\mathrm{R}$ & 5.09 & 128.96 & 94.61 & 46.44 & 0.58 & 90.29 \\
\hline ZWB10_76 & MR & 5.36 & 129.40 & 99.08 & 47.03 & 0.60 & 89.76 \\
\hline ZWB11_153 & MS & 4.73 & 129.06 & 99.98 & 49.49 & 0.60 & 91.83 \\
\hline ZWB11_172 & $\mathrm{R}$ & 5.07 & 130.97 & 97.13 & 45.16 & 0.57 & 91.37 \\
\hline ZWB11_95 & MR & 5.57 & 130.55 & 94.10 & 44.15 & 0.58 & 90.54 \\
\hline ZWB12_103 & MS & 5.33 & 128.96 & 94.81 & 51.79 & 0.59 & 91.94 \\
\hline ZWB12_121 & MS & 4.75 & 128.68 & 94.32 & 47.88 & 0.60 & 91.19 \\
\hline ZWB12_122 & MS & 5.16 & 129.22 & 95.93 & 47.63 & 0.63 & 89.61 \\
\hline ZWB12_123 & MS & 4.71 & 129.58 & 92.15 & 52.55 & 0.58 & 93.66 \\
\hline ZWB12_124 & MS & 4.93 & 128.26 & 88.84 & 52.70 & 0.57 & 93.69 \\
\hline ZWB12_14 & $\mathrm{R}$ & 4.97 & 129.23 & 96.78 & 48.14 & 0.61 & 91.46 \\
\hline ZWB12_147 & MS & 4.65 & 128.43 & 96.26 & 51.82 & 0.61 & 93.46 \\
\hline ZWB12_158 & MS & 4.73 & 128.72 & 101.65 & 47.69 & 0.59 & 92.88 \\
\hline ZWB12_16 & S & 5.14 & 128.40 & 93.55 & 46.60 & 0.58 & 92.34 \\
\hline ZWB12_168 & S & 5.13 & 130.14 & 93.86 & 49.10 & 0.58 & 93.11 \\
\hline ZWB12_18 & MR & 4.57 & 128.84 & 92.68 & 49.05 & 0.58 & 93.02 \\
\hline ZWB12_187 & MR & 5.56 & 130.75 & 99.05 & 48.18 & 0.62 & 91.03 \\
\hline ZWB12_189 & MS & 4.82 & 127.85 & 97.52 & 43.74 & 0.60 & 90.55 \\
\hline ZWB12_194 & MS & 4.79 & 128.53 & 94.78 & 48.26 & 0.59 & 92.55 \\
\hline ZWB12_202 & $\mathrm{S}$ & 4.89 & 128.75 & 94.30 & 50.25 & 0.55 & 94.61 \\
\hline ZWB12_219 & MS & 4.75 & 130.45 & 96.43 & 44.21 & 0.52 & 88.04 \\
\hline ZWB12_24 & MS & 4.91 & 129.47 & 98.90 & 47.51 & 0.60 & 92.98 \\
\hline ZWB12_29 & MS & 5.31 & 130.32 & 95.10 & 49.92 & 0.61 & 91.83 \\
\hline ZWB12_30 & $\mathrm{R}$ & 5.17 & 129.73 & 100.39 & 50.20 & 0.59 & 90.88 \\
\hline ZWB12_31 & MR & 5.32 & 129.60 & 98.16 & 51.10 & 0.60 & 93.32 \\
\hline ZWB12_4 & MR & 5.20 & 129.48 & 95.07 & 48.22 & 0.59 & 90.91 \\
\hline ZWB12_42 & MS & 5.25 & 128.84 & 91.86 & 48.29 & 0.60 & 92.47 \\
\hline ZWB12_62 & MR & 4.80 & 129.33 & 91.24 & 45.91 & 0.59 & 90.12 \\
\hline ZWB12_63 & MS & 4.73 & 129.11 & 94.99 & 46.19 & 0.58 & 89.93 \\
\hline ZWB12_67 & MS & 5.15 & 129.40 & 94.55 & 46.79 & 0.58 & 90.96 \\
\hline ZWB12_86 & MS & 5.27 & 128.11 & 95.54 & 51.17 & 0.60 & 93.19 \\
\hline
\end{tabular}

\section{QTL Identification}

There was an evident association between genetic groups and Karnal bunt resistance in the population, as majority of the lines in Pop3 were resistant, and separate from the other groups in the DAPC space (Figure 1B). This association of population group with resistance was statistically significant, as determined from a chi-square test of independence $\left(X^{2}=54.81\right.$, $P$-value $<0.001)$, hence, corrective measures were applied to adjust for the potential bias in declaring QTL identification.

A Kinship-corrected GWAS analysis identified six markers that were significantly associated with Karnal bunt resistance, after controlling for multiple testing using both the genomewide threshold and FDR criteria (Table 1 and Figure 3A). We compared different mixed models and found the kinship model as the most effective to correct for population structure, as it produced the lowest genomic inflation factor (lambda, $\lambda \mathrm{gc}=1.03)$, and the observed $P$-values showed little deviations from the expected (Figure 3B). Surprisingly, all the significant markers were in the A and $\mathrm{B}$ genomes, and physically localised to the long arms of chromosomes $1 \mathrm{~A}, 2 \mathrm{~A}, 3 \mathrm{~B}, 4 \mathrm{~A}, 5 \mathrm{~A}$, and 6B (Table 1). The markers explained a large proportion (7.6$29.5 \%)$ of the variation in Karnal bunt resistance, and when favourable alleles were considered, genotypes with a high number of beneficial alleles were completely resistant to Karnal bunt infection (Figure 3C).

\section{Genomic Prediction}

There was no difference in prediction accuracy between the QGBLUP approach and the whole-genome prediction (GBLUP) approach (Figure 4). In the QGBLUP approach, the prediction ability for Karnal bunt resistance averaged $0.53 \pm 0.003$, and in the alternate approach of whole genome marker prediction, the accuracy averaged $0.56 \pm 0.01$. In effect, genomic prediction using a few, trait-specific markers produced accuracies that compared favourably with those from whole-genome markers.

\section{Agronomic Profiles}

In the agronomic experiments, estimates of trait heritability, independent of year and heterogeneous field conditions, were consistently high across traits (Table 2), indicating strong genotypic main effects. The adjusted trait means were analysed using the GGE biplot method to allow visual examination of genotype performance across multiple traits, and identification of superior individuals. The biplot captured $87.7 \%$ of total variability in the data (Figure 5) and is therefore appropriate for visualising the relationships among traits. All traits were equally important, as indicated by the relative length of their vectors. The biplot showed that grain yield was positively related to growth duration and biomass production (acute angles), negatively related to plant height (obtuse angle), and independent of grain size (near right angles). When the "which-won-where" function was used to partition the data into a two-dimensional polygon view, the agronomic traits were grouped into three major sectors (Figure 5A): phenology (flowering time/plant height), grain yield (grain yield/NDVI), and grain size (1,000kernel weight/grain plumpness). Vertex genotypes in each sector 

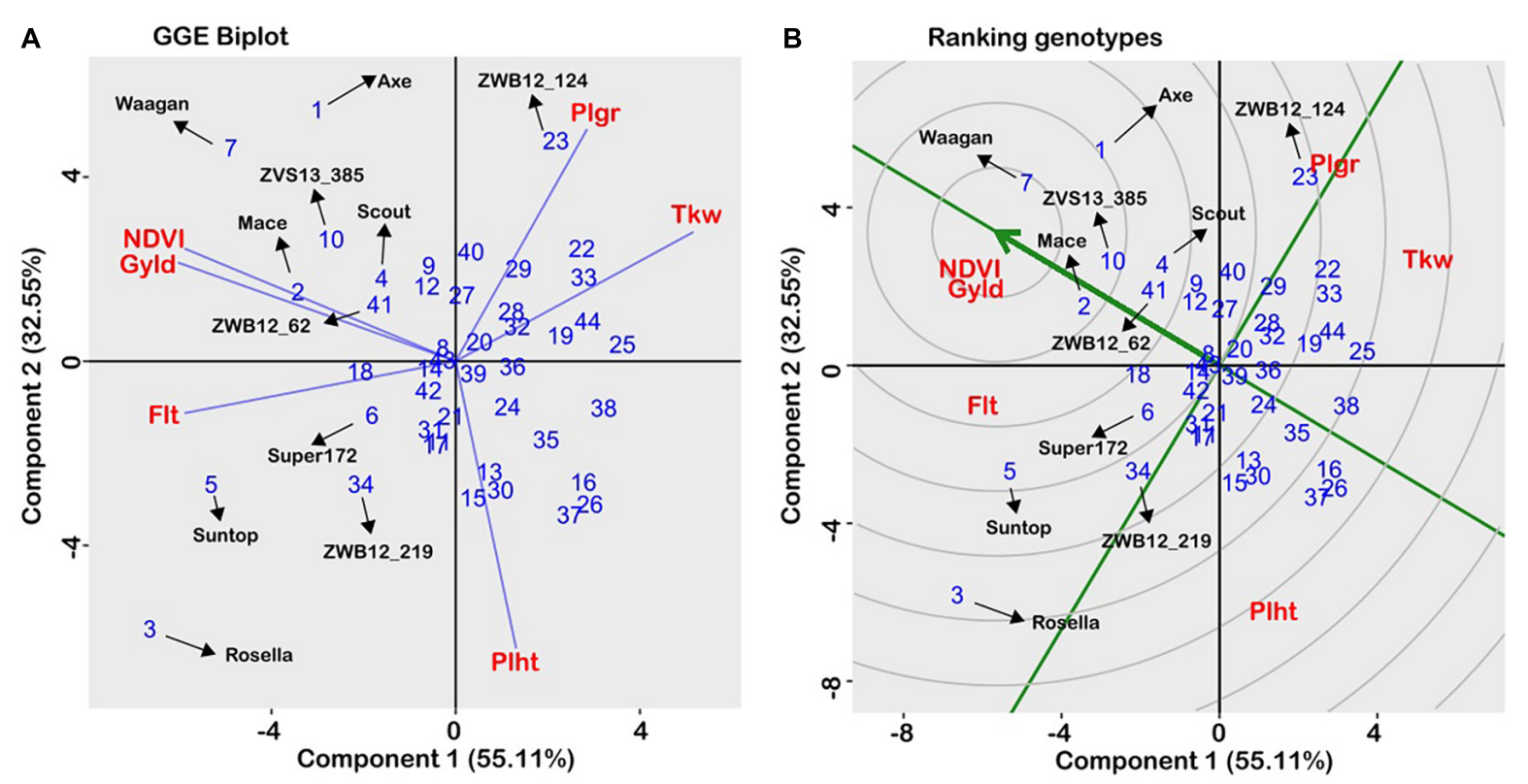

FIGURE 5 | GGE biplot of a genotype $\times$ trait matrix averaged over two years, using trait-focussed SVP, and Double-Centred GE with scaling by standard deviation. (A) Polygon plot of "which won where." The numbers refer to individual wheat accessions (see Table 1), and abbreviations are given for trait names. Flt, flowering time; Gyld, Grain yield; NDVI, Normalised difference vegetative index; Tkw, Thousand kernel weight; Plht, Plant height. (B) Ranking the accessions in relation to the "ideal" genotype.

are considered the best/worst for traits within the sector (Yan and Rajcan, 2002). Thus, the late-maturing variety, Rosella, was placed at the apex of the phenology sector, while early maturing varieties, Waagan and Axe, were placed at the vertex of the grain yield sector (Figure 5A). These varieties were positioned opposite to the plant height vector, which is consistent with the negative relationship between plant height and grain yield. Of the CIMMYT-derived accessions, ZWB12-124 and ZWB12_147, had the best agronomic values for grain size/plumpness, while ZWB12_158 and ZWB12_30 were the worst for plant height (Figure 5A). The mean trait value for all genotypes are presented in Table 2 to validate the interpretations.

The GGE biplot can also be used to visualise genotype ranking against the "ideal." The "ideal" is defined as a genotype that combines all favourable attributes, and in Figure 5B, the arrow indicates where the ideal genotype should be. Accordingly, the ideal genotype is expected to be high yielding, early maturing and below average in plant height. A performance line passing through the origin is used as a reference, and a genotype closer to the "ideal" is considered more desirable than those further away. As shown in Figure 5B, Waagan, followed by Mace and Axe are the more desirable of the check varieties, while Rosella and Suntop were far from the ideal genotype. Of the Karnal bunt-resistant accessions, ZVS13-385 and ZWB1262 were the closest to the ideal genotype (Figure 5B). In particular, the genotype ZVS13-385 was placed within the same concentric ring as Mace, which meant it had similar agronomic attributes. This is relevant information, as Mace is one of the most widely grown varieties in Australia. DNA analysis showed that ZVS13-385 possessed all six of the favourable alleles identified for Karnal bunt resistance, and therefore would be suitable as a parent for transferring resistance into commercially acceptable backgrounds.

\section{DISCUSSION}

In the first part of this study, we sought to dissect the genetic basis of Karnal bunt resistance, as the information is essential for confirming resistance sources, identifying those most suitable as donor parental lines, and designing strategies to accelerate transfer of resistance into commercial cultivars. We identified six DArTseq markers, which explained between 7.6 and $29.5 \%$ of the observed phenotypic variation and were located at chromosome positions previously reported in the literature (Bishnoi et al., 2020). When BLASTN search was conducted against the IWGSC RefSeq v1.0 Chinese Spring assembly, the most frequently identified putative candidate gene at the QTLs encoded the F-box domain containing proteins. The F-box proteins are a large superfamily that play pivotal roles in host-pathogen interactions through targeting substrates into the degradation machinery (Cao et al., 2008).

The knowledge that Karnal bunt resistance is mediated by multiple genes is supported by previous studies, but this introduces another dimension to the difficulties of breeding for resistance in the absence of the pathogens (Emebiri et al., 2019b). The multi-gene control implies that marker-assisted selection by pyramiding or stacking of favourable alleles may not be successful (Langridge and Waugh, 2019), because interactions among QTL/genes and environmental factors can make substantial 
contributions to variation in complex traits such as disease susceptibility (Carlborg and Haley, 2004). As suggested in Emebiri et al. (2019b), new and innovative strategies will be required, and in this study, we assessed the potentials of the method of genomic prediction as a pre-emptive breeding tool. For developing the prediction model, we compared the traditional use of whole-genome markers against the use of a few significant markers identified by GWAS and found the prediction abilities to be comparable (Figure 4). This was not surprising, as genomic prediction accuracy is highly dependent on the LD between the genotyped markers and actual causative variants (de Los Campos et al., 2013). The use of significant trait-specific markers was expected to improve genomic prediction, and in fact, prior marker selection has been suggested as a strategy to increase reliability of the genomic estimated breeding values (Brøndum et al., 2015). Rutkoski et al. (2012) reported that in wheat, genomic predictions based on QTL targeted markers for fusarium head blight resistance (deoxynivalenol) alone were higher than predictions based on genome-wide markers. Other researchers have also found higher prediction abilities of the MAS approach over whole-genome prediction (Slavov et al., 2014; Zhao et al., 2014; Boeven et al., 2016), but Gaikpa et al. (2020) found the opposite to be the case. Similarly, while some researchers have found that use of trait-specific markers as fixed factors increased accuracy of genomic prediction (e.g., Daetwyler et al., 2014), others have observed no difference (e.g., Rice and Lipka, 2019). Invariably, this will vary with trait, and the performance of such a prediction model should be explored on a trait-by-trait basis prior to its implementation in a breeding programme (Rice and Lipka, 2019). Karnal bunt resistance in this population showed high heritability $(0.83 \pm 0.02)$, hence marker-based prediction accuracies were almost comparable to genome-wide prediction accuracies. This may not be the case in different populations, but the possibility of using a few significant markers for genomic prediction would augur well for preemptive breeding against Karnal bunt infection in countries that are free of the disease, where phenotyping would be difficult and the costs for high-density genotyping can be limiting. This is a subject that requires further investigation, as large-scale studies are showing that, in a high LD crop like wheat, highdensity genomic coverage has minimal impact on the genomic predictabilities (Juliana et al., 2019).

The identification of parental lines combining Karnal bunt resistance with adaptive agronomic traits is key to pre-emptive breeding, as it addresses breeder's concerns regarding yield penalty in the absence of the disease. Plant breeders use the GGE biplot technique for prioritising genotypes for use as parents in varietal improvement as the regular stability analysis does not provide information on the relative ranking of entries with reference to an ideal genotype (Yan and Kang, 2003). The current research carried out a comprehensive examination of Karnal bunt resistant germplasm from CIMMYT and has identified an ideal genotype, ZVS13_385 (TAM200/PASTOR//TOBA97/3/HEILO), which showed agronomic similarity to the highly successful Australian wheat variety, Mace (Moffat et al., 2015; Table 2; Figure 5B). Furthermore, ZVS13_385 is phenotypically resistant to Karnal bunt infection ( $<1 \%$ infection), and possessed all favourable alleles detected for major and minor QTL linked to resistance. This means that it could be used directly as a cultivated variety, or as an ideal genotype for use in the crossing block. We conclude that the identification of a genotype combining Karnal bunt resistance with adaptive agronomic traits negates the concerns of breeders regarding yield penalty in the absence of the disease. Using mathematical modelling, Vyska et al. (2016) showed that even when disease outbreak is uncertain, growing resistant varieties is an optimal strategy for crop protection as it reduces the probability of an outbreak occurring. We add that wide availability of Karnal bunt resistant lines may encourage countries to relax the zero-tolerance regulation that currently exists for Karnal bunt, which is quite costly to implement (Babadoost, 2000; Vocke et al., 2010).

\section{DATA AVAILABILITY STATEMENT}

The raw phenotypic data supporting the findings of this article are available and accessible through the CIMMYT-AustraliaICARDA Germplasm Evaluation (CAIGE) suite of related projects (Biosecurity risk - CAIGE (caigeproject.org.au). The genotypic data can be made available by the senior author with no reservations.

\section{AUTHOR CONTRIBUTIONS}

LE conceived the study and drafted the manuscript. SH conducted the agronomic experiments. M-KT conducted DNA extractions and supervised the genotyping work. PJ assisted with data analyses. PS, GF-D, and RS conducted the Karnal bunt screening experiments. All authors read and revised the manuscript.

\section{FUNDING}

This study was funded jointly by grants from the Grains Research \& Development Corporation (GRDC), The NSW Department of Primary Industry (NSW DPI, Australia), and the International Maize and Wheat Improvement Center (CIMMYT, Mexico) under Grant Number DAN00174.

\section{ACKNOWLEDGMENTS}

We thank the CGIAR Research Program on Wheat for their support. We also thank all field technicians involved in generating the field and laboratory data.

\section{SUPPLEMENTARY MATERIAL}

The Supplementary Material for this article can be found online at: https://www.frontiersin.org/articles/10.3389/fpls.2021. 675859/full\#supplementary-material 


\section{REFERENCES}

Andreescu, C., Avendano, S., Brown, S. R., Hassen, A., Lamont, S. J., and Dekkers, J. C. (2007). Linkage disequilibrium in related breeding lines of chickens. Genetics 177, 2161-2169. doi: 10.1534/genetics.107.082206

Anonymous (2020). The Old, the New and the Newt. Norwich: John Innes Centre, Norwich Research Park.

Babadoost, M. (2000). Comments on the zero-tolerance quarantine of Karnal bunt of wheat. Plant Dis. 84, 711-712. doi: 10.1094/pdis.2000.84.7.711

Babadoost, M., Mathre, D. E., Johnston, R. H., and Bonde, M. R. (2004). Survival of teliospores of Tilletia indica in soil. Plant Dis. 88, 56-62. doi: 10.1094/pdis. 2004.88.1.56

Beattie, B. R., and Biggerstaff, D. R. (1999). Karnal bunt: a wimp of a disease. but an irresistible political opportunity. Choices 14:5.

Benjamini, Y., and Hochberg, Y. (1995). Controlling the false discovery rate: a practical and powerful approach to multiple testing. J. R. Statist. Soc. B 57, 289-300. doi: 10.1111/j.2517-6161.1995.tb02031.x

Bishnoi, S. K., He, X., Phuke, R. M., Kashyap, P. L., Alakonya, A., Chhokkar, V., et al. (2020). Karnal bunt: a re-emerging old foe of wheat. Front. Plant Sci. 11:569057. doi: 10.3389/fpls.2020.569057

Boeven, P. H., Longin, C. F., Leiser, W. L., Kollers, S., Ebmeyer, E., and Würschum, T. (2016). Genetic architecture of male floral traits required for hybrid wheat breeding. Theor. Appl. Genet. 129, 2343-2357. doi: 10.1007/s00122-016-2771-6

Brar, G. S., Fuentes-Dávila, G., He, X., Sansaloni, C. P., Singh, R. P., and Singh, P. K. (2018). Genetic mapping of resistance in hexaploid wheat for a quarantine disease: Karnal bunt. Front. Plant Sci. 9:1497. doi: 10.3389/fpls.2018.01497

Breseghello, F., and Sorrells, M. E. (2006). Association mapping of kernel size and milling quality in wheat (Triticum aestivum L.) cultivars. Genetics 172, 1165-1177. doi: 10.1534/genetics.105.044586

Brøndum, R. F., Su, G., Janss, L., Sahana, G., Guldbrandtsen, B., Boichard, D., et al. (2015). Quantitative trait loci markers derived from whole genome sequence data increases the reliability of genomic prediction. J. Dairy Sci. 98, 4107-4116. doi: $10.3168 /$ jds.2014-9005

Brown, J. K. (2002). Yield penalties of disease resistance in crops. Curr. Opin. Plant Biol. 5, 339-344. doi: 10.1016/s1369-5266(02)00270-4

Buels, R., Yao, E., Diesh, C. M., Hayes, R. D., Munoz-Torres, M., Helt, G., et al. (2016). JBrowse: a dynamic web platform for genome visualization and analysis. Genome Biol. 17:66.

Cao, Y., Yang, Y., Zhang, H., Li, D., Zheng, Z., and Song, F. (2008). Overexpression of a rice defense-related F-box protein gene OsDRF1 in tobacco improves disease resistance through potentiation of defense gene expression. Physiol. Plant. 134, 440-452. doi: 10.1111/j.1399-3054.2008.0 1149.x

Carlborg, Ö, and Haley, C. S. (2004). Epistasis: too often neglected in complex trait studies? Nat. Rev. Genet. 5, 618-625. doi: 10.1038/nrg1407

Chhibber-Goel, J., Gaur, A., Singhal, V., Parakh, N., Bhargava, B., and Sharma, A. (2016). The complex metabolism of trimethylamine in humans: endogenous and exogenous sources. Expert Rev. Mol. Med. 18:e8.

Chhuneja, P., Kaur, S., Singh, K., and Dhaliwal, H. S. (2008). Evaluation of Aegilops tauschii (Coss.) germplasm for Karnal bunt resistance in a screen house with simulated environmental conditions. Plant Genet. Resour. 6, 79-84. doi: 10. $1017 /$ s1479262108982654

Covarrubias-Pazaran, G. (2016). Genome-assisted prediction of quantitative traits using the R package sommer. PLoS One 11:e0156744. doi: 10.1371/journal.pone. 0156744

Cullis Brian, R., Smith, A. B., and Coombes, N. E. (2006). On the design of early generation variety trials with correlated data. J. Agric. Biol. Environ. Stat. 11, 381-393. doi: 10.1198/108571106x154443

Daetwyler, H. D., Bansal, U. K., Bariana, H. S., Hayden, M. J., and Hayes, B. J. (2014). Genomic prediction for rust resistance in diverse wheat landraces. Theor. Appl. Genet. 127, 1795-1803.

de Los Campos, G., Vazquez, A. I., Fernando, R., Klimentidis, Y. C., and Sorensen, D. (2013). Prediction of complex human traits using the genomic best linear unbiased predictor. PLoS Genet. 9:e1003608. doi: 10.1371/journal. pgen. 1003608

Emebiri, L., Singh, P. K., Tan, M. K., Fuentes-Davila, G., He, X., and Singh, R. P. (2019a). Reaction of Australian durum, common wheat, and triticale genotypes to Karnal bunt (Tilletia indica) infection under artificial inoculation in the field. Crop Pasture Sci. 70, 107-112. doi: 10.1071/cp18235

Emebiri, L., Singh, S., Tan, M. K., Singh, P. K., Fuentes-Dávila, G., and Ogbonnaya, F. (2019b). Unravelling the complex genetics of Karnal bunt (Tilletia indica) resistance in common wheat (Triticum aestivum) by genetic linkage and genome-wide association analyses. G3 Genes Genomes Genet. 9, 1437-1447. doi: $10.1534 / \mathrm{g} 3.119 .400103$

Food and Agriculture Organization (2009). "How to Feed the World in 2050," in Executive Summary-Proceedings of the Expert Meeting on How to Feed the World in 20502009 Oct 12, (Rome: Food and Agriculture Organization).

Frutos, E., Galindo, M. P., and Leiva, V. (2014). An interactive biplot implementation in $\mathrm{R}$ for modelling genotype-by-environment interaction. Stochastic Environ. Res. Risk Assess. 28, 1629-1641. doi: 10.1007/s00477-0130821-z

Fuentes-Davila, G. (1996). "Karnal bunt," in Bunt and Smut Diseases of Wheat: Concepts and Methods of Disease Management, eds R. D. Wilcoxson and E. E. Saari (Mexico: CIMMYT), 26-32. doi: 10.17221/6226-cjgpb

Fuentes-Dávila, G., Prakash-Singh, R., Rosas-Jáuregui, I. A., Ayón-Ibarra, C. A., Félix-Valencia, P., Félix-Fuentes, J. L., et al. (2018). Evaluating advanced bread wheat lines for Karnal bunt resistance in the field during the 2012-2013 crop season. Annu. Wheat Newslett. 64, 25-30.

Fuentes-Dávila, G., and Rajaram, S. (1994). Sources of resistance to Tilletia indica in wheat (Triticum aestivum). Crop Protect. 13, 20-24. doi: 10.1016/02612194(94)90131-7

Fuentes-Dávila, G., Rajaram, S., and Singh, G. (1995). Inheritance of resistance to Karnal bunt (Tilletia indica Mitra) in bread wheat (Triticum aestivum L.). Plant Breed. 114, 250-252. doi: 10.1111/j.1439-0523.1995.tb00804.x

Gaikpa, D. S., Koch, S., Fromme, F. J., Siekmann, D., Würschum, T., and Miedaner, T. (2020). Genome-wide association mapping and genomic prediction of Fusarium head blight resistance, heading stage and plant height in winter rye (Secale cereale). Plant Breed. 139, 508-520. doi: 10.1111/pbr.12810

Gaudet, D. A., Fuentes-Davila, G., De Pauw, R. M., and Burnett, P. A. (2001). Reactions of western Canadian spring wheat and triticale varieties to Tilletia indica, the causal agent of Karnal bunt. Can. J. Plant Sci. 81, 503-508. doi: 10.4141/p00-067

Ginestet, C. (2011). ggplot2: elegant graphics for data analysis. J. R. Stat. Soc. Ser. A 174, 245-246. doi: 10.1111/j.1467-985x.2010.00676_9.x

Gupta, V., He, X., Kumar, N., Fuentes-Davila, G., Sharma, R. K., Dreisigacker, S., et al. (2019). Genome wide association study of Karnal bunt resistance in a wheat germplasm collection from Afghanistan. Int. J. Mol. Sci. 20:3124. doi: $10.3390 /$ ijms 20133124

Gutierrez, L., Quero, G., Fernandez, S., and Brandariz, S. (2016). Imem.Gwaser: Linear Mixed Effects Models for Genome-Wide Association Studies. R package version 0.1.0.

Jombart, T. (2008). adegenet: a R package for the multivariate analysis of genetic markers. Bioinformatics 24, 1403-1405. doi: 10.1093/bioinformatics/btn129

Jombart, T., Devillard, S., and Balloux, F. (2010). Discriminant analysis of principal components: a new method for the analysis of genetically structured populations. BMC Genet. 11:94. doi: 10.1186/1471-2156-11-94

Jorgensen, J. H. (1992). Discovery, characterization, and exploitation of Mlo powdery mildew resistance in barley. Euphytica 63, 141-152. doi: 10.1007/ bf00023919

Joshi, L. M., Singh, D. V., Srivastava, K. D., and Wilcoxson, R. D. (1983). Karnal bunt: a minor disease that is now a threat to wheat. Bot. Rev. 49, 309-330. doi: $10.1007 / \mathrm{bf} 02861085$

Joukhadar, R., Hollaway, G., Shi, F., Kant, S., Forrest, K., Wong, D., et al. (2020). Genome-wide association reveals a complex architecture for rust resistance in 2300 worldwide bread wheat accessions screened under various Australian conditions. Theor. Appl. Genet. 133, 2695-2712. doi: 10.1007/s00122-02003626-9

Juliana, P., Poland, J., and Huerta-Espino, J. (2019). Improving grain yield, stress resilience and quality of bread wheat using large-scale genomics. Nat. Genet. 51, 1530-1539. doi: 10.1038/s41588-019-0496-6

Kumar, M., Luthra, O. P., Yadav, N. R., Chaudhary, L., Saini, N., Kumar, R., et al. (2007). Identification of micro satellite markers on chromosomes of bread wheat showing an association with Karnal bunt resistance. Afr. J. Biotechnol. $6,1617-1622$. 
Kumar, S., Chawla, V., Yadav, N. R., Sharma, I., Yadav, P. K., Kumar, S., et al. (2015). Identification and validation of SSR markers for Karnal bunt (Neovossia indica) resistance in wheat (Triticum aestivum). Indian J. Agric. Sci. 85, 712-717.

Kaur, M., Singh, R., Kumar, S., Mandhan, R. P., and Sharma, I. (2016). Identification of QTL conferring Karnal bunt resistance in wheat. Indian J. Biotechnol. 15, 34-38.

Langridge, P., and Waugh, R. (2019). Harnessing the potential of germplasm collections. Nat. Genet. 51, 200-201. doi: 10.1038/s41588-018-0340-4

Li, J., and Ji, L. (2005). Adjusting multiple testing in multilocus analyses using the eigenvalues of a correlation matrix. Heredity 95, 221-227. doi: 10.1038/sj.hdy. 6800717

Linehan, V., Thorpe, S., Andrews, N., Kim, Y., and Beaini, F. (2012). "Food demand to 2050: opportunities for Australian agriculture," in Paper Presented at the 42nd ABARES Outlook Conference 6-7 March 2012, (Canberra: ACT).

Meuwissen, T. H. E., Hayes, B. J., and Goddard, M. E. (2001). Prediction of total genetic value using genome-wide dense marker maps. Genetics 157, 1819-1829. doi: $10.1093 /$ genetics/157.4.1819

Mitra, M. (1935). Studies on the stinking smut (bunt) of wheat with a special reference to Tilletia indica Mitra. Indian J. Agric. Sci. 5, 1-24.

Moffat, C. S., See, P. T., and Oliver, R. P. (2015). Leaf yellowing of the wheat cultivar Mace in the absence of yellow spot disease. Austral. Plant Pathol. 44, 161-166. doi: 10.1007/s13313-014-0335-2

Mujeeb-Kazi, A., Fuentes-Davilla, G., Gul, A., and Mirza, J. I. (2006). Karnal bunt resistance in synthetic hexaploid wheats $(\mathrm{SH})$ derived from durum wheat $\times$ Aegilops tauschii combinations and in some $\mathrm{SH} \times$ bread wheat derivatives. Cereal Res. Commun. 34, 1199-1205. doi: 10.1556/crc.34.2006.4.259

Murray, G., and Brennan, J. (1998). The risk to Australia from Tilletia indica, the cause of Karnal bunt of wheat. Austral. J. Plant Pathol. 27, 212-225. doi: 10.1071/ap98024

Nelson, J. C., Autrique, J. E., Fuentes-Dávila, G., and Sorrells, M. E. (1998). Chromosomal location of genes for resistance to Karnal bunt in wheat. Crop Sci. 38, 231-236.

Ning, Y., Liu, W., and Wang, G. L. (2017). Balancing immunity and yield in crop plants. Trends Plant Sci. 22, 1069-1079. doi: 10.1016/j.tplants.2017.09.010

Oliver, R., Lichtenzveig, J., Tan, K.-C., Waters, O., Rybak, K., Lawrence, J., et al. (2014). Absence of detectable yield penalty associated with insensitivity to Pleosporales necrotrophic effectors in wheat grown in the West Australian wheat belt. Plant Pathol. 63, 1027-1032. doi: 10.1111/ppa.12191

Poland, J., and Rutkoski, J. (2016). Advances and challenges in genomic selection for disease resistance. Annu. Rev. Phytopathol. 54, 79-98. doi: 10.1146/ annurev-phyto-080615-100056

Purcell, S., Neale, B., Todd-Brown, K., Thomas, L., Ferreira, M. A., Bender, D., et al. (2007). PLINK: a tool set for whole-genome association and population-based linkage analyses. Am. J. Hum. Genet. 81, 559-575. doi: 10.1086/519795

Rice, B., and Lipka, A. E. (2019). Evaluation of RR-BLUP genomic selection models that incorporate peak genome-wide association study signals in maize and sorghum. Plant Genome 12, 1-4.

Rodríguez-Álvarez, M. X., Boer, M. P., van Eeuwijk, F. A., and Eilers, P. H. (2018). Correcting for spatial heterogeneity in plant breeding experiments with P-splines. Spat. Stat. 23, 52-71. doi: 10.1016/j.spasta.2017.10.003

Rutkoski, J., Benson, J., Jia, Y., Brown-Guedira, G., Jannink, J. L., and Sorrells, M. (2012). Evaluation of genomic prediction methods for Fusarium head blight resistance in wheat. Plant Genome 5.

Sharp, G. L., Martin, J. M., Lanning, S. P., Blake, N. K., Brey, C. W., Sivamani, E., et al. (2002). Field evaluation of transgenic and classical sources of wheat streak mosaic virus resistance. Crop Sci. 42, 105-110. doi: 10.2135/cropsci2002.1050

Singh, R., Fuentes, G., Autrique, E., Huerta-Espino, J., and Singh, P. (2016). "Identification and distribution of new high yielding genotypes with resistance to Karnal bunt of wheat," in Proceedings of the XIX International Workshop on Smuts and Bunts, Logan.

Singh, S., Sehgal, D., Kumar, S., Arif, M. A., Vikram, P., Sansaloni, C. P., et al. (2020). GWAS revealed a novel resistance locus on chromosome 4D for the quarantine disease Karnal bunt in diverse wheat pre-breeding germplasm. Sci. Rep. 10:5999.

Singh, S., Brown-Guedira, G. L., Grewal, T. S., Dhaliwal, H. S., Nelson, J. C., Singh, H., et al. (2003). Mapping of a resistance gene effective against Karnal bunt pathogen of wheat. Theor. Appl. Genet. 106, 287-292.

Singh, S., Sharma, I., Sehgal, S. K., Bains, N. S., Guo, Z., Nelson, J. C., et al. (2007). Molecular mapping of QTLs for Karnal bunt resistance in two recombinant inbred populations of bread wheat. Theor. Appl. Genet. 116, 147-154. doi: 10.1007/s00122-007-0654-6

Singh, S., Vargas, M., Crossa, J., Singh, P. K., Bains, N. S., Singh, K., et al. (2012). Multi trait and multi-environment QTL analyses for resistance to wheat diseases. PLoS One 7:e38008. doi: 10.1371/journal.pone.0038008

Slavov, G. T., Nipper, R., Robson, P., Farrar, K., Allison, G. G., Bosch, M., et al. (2014). Genome-wide association studies and prediction of 17 traits related to phenology, biomass and cell wall composition in the energy grass Miscanthus sinensis. New Phytol. 201, 1227-1239. doi: 10.1111/nph.12621

Stekhoven, D. J., and Bühlmann, P. (2012). MissForest - non-parametric missing value imputation for mixed-type data. Bioinformatics 28, 112-118. doi: 10 . 1093/bioinformatics/btr597

Tan, M.-K., El Bouhssini, M., Emebiri, L. C., Wildman, O., Tadesse, W., and Ogbonnaya, F. C. (2015). A SNP marker for the selection of HfrDrd, a Hessian fly-response gene in wheat. Mol. Breed. 35:216.

Vocke, G., Allen, E., and Price, J. M. (2010). The Economic Impact of Karnal Bunt Phytosanitary Wheat Export Certificates. Outlook Report No. WHS-10h-01. Washington, DC: US Department of Agriculture, Economic Research Service.

Vyska, M., Cunniffe, N., and Gilligan, C. (2016). Trade-off between disease resistance and crop yield: a landscape-scale mathematical modelling perspective. J. R. Soc. Interf. 13:20160451. doi: 10.1098/rsif.201 6.0451

Warham, E. J. (1986). Karnal bunt disease of wheat: a literature review. Trop. Pest Manag. 32, 229-242. doi: 10.1016/b978-0-12-819527-7.00015-7

White, B., Day, C., Christopher, M., and van Klinken, R. (2016). Should we Invest Now in Cereal Pre-Breeding for Biosecurity Threats? Working Paper 1605, School of Agricultural and Resource Economics, University of Western Australia, Crawley, Australia. Available online at: https://ideas.repec.org/p/ags/ uwauwp/236736.html (assessed 12 June, 2021).

Yan, W., and Kang, M. S. (2003). GGE Biplot Analysis: A Graphical Tool for Breeders, Geneticists, and Agronomists. Boca Raton, FL: CRC press.

Yan, W., and Rajcan, I. (2002). Biplot analysis of test sites and trait relations of soybean in Ontario. Crop Sci. 42, 11-20. doi: 10.2135/cropsci2002. 0011

Zhao, Y., Mette, M. F., Gowda, M., Longin, C. F., and Reif, J. C. (2014). Bridging the gap between marker-assisted and genomic selection of heading time and plant height in hybrid wheat. Heredity 112, 638-645. doi: 10.1038/hdy. 2014.1

Conflict of Interest: The authors declare that the research was conducted in the absence of any commercial or financial relationships that could be construed as a potential conflict of interest.

Publisher's Note: All claims expressed in this article are solely those of the authors and do not necessarily represent those of their affiliated organizations, or those of the publisher, the editors and the reviewers. Any product that may be evaluated in this article, or claim that may be made by its manufacturer, is not guaranteed or endorsed by the publisher.

Copyright (c) 2021 Emebiri, Hildebrand, Tan, Juliana, Singh, Fuentes-Davila and Singh. This is an open-access article distributed under the terms of the Creative Commons Attribution License (CC BY). The use, distribution or reproduction in other forums is permitted, provided the original author(s) and the copyright owner(s) are credited and that the original publication in this journal is cited, in accordance with accepted academic practice. No use, distribution or reproduction is permitted which does not comply with these terms. 